TANULMÁNYOK 2019/1. Bölcsészettudományi Kar, Újvidék

STUDIJE 2019/1. Filozofski fakultet, Novi Sad

STUDIES 2019/1. Faculty of Philosophy, Novi Sad

ETO: 821.511.141-32NÁDAS P.

ORIGINAL SCIENTIFIC PAPER

DOI: $10.19090 / \mathrm{tm} .2019 .1 .45-56$

A kézirat leadásának időpontja: 2019. augusztus 29.

Az elfogadás időpontja: 2019. szeptember 26.

\author{
BANDI Irén \\ Ohridi Szent Kelemen Tudományegyetem \\ Klasszika Filológia és Modern Filológiák Kara \\ Klasszika Filológia és Magyar Filológia Tanszék \\ Szófia, Bulgária \\ irenbandi@hotmail.com
}

\title{
AZ EMLÉKEZÉSTŐL AZ ELBESZÉLÉSIG
}

Nádas Péter Világló részletek címü müvének köztes terei

\section{Od prisećanja do pripovedanja}

Međuprostori u delu Petera Nadaša Világló részletek (Svetli detalji)

\section{From Remembering to Story-Telling}

\section{Intermediate Spaces of Péter Nádas's Work Világló részletek (Bright Details)}

Ebben a tanulmányban Nádas Péter Világló részletek című művének köztes tereit vizsgálom, pontosabban az elbeszélő én tudatmozgásának irányait próbálom feltárni. A tanulmány első részében azt igyekszem átlátni, hogy az elbeszélő hogyan lép át a jelent közvetlenül érzékelő tudat határán, hogyan talál rá a múlt emlékeire, illetve azt, hogy miként képes a saját belső utazását tárgyilagosan megfigyelni és rögzíteni. A tanulmány második részében az a kérdés is felmerül, hogy az elbeszélő hogyan lép túl saját szubjektív élményein, és hogyan jut el olyan világtapasztalatokhoz, melyek nem az ő közvetlen megismerésének részei. A második részben tehát azt szeretném nyomon követni, hogy az elbeszélő - mellőzve a fikció és a képzelet eszközeit - hogyan jut el a közös történetekig, hogyan lépi át azt a köztes teret, melyet a megismerésre törekvő elme az én és a te, az én és a másik világa között óhatatlanul érzékel. Kulcsszavak: személyes emlékezet, kollektív emlékezet, interszubjektív tér, élettörténet, emlékiratok

Az alábbiakban Nádas Péter Világló részletek címü müvén belül szeretném vizsgálni azokat az átmeneteket, átmeneti sávokat, amelyeket az elbeszélő én különböző világpercepciói között vélek felfedezni. Milyen határokat lép át az 
elbeszélő a különböző valóságszintekhez köthető tudatmozgása során? Milyen utakat jár be az emlékező tudat? És hogyan jut el az elbeszélő az emlékezéstől az elbeszélésig?

Úgy tűnik, hogy e több mint ezeroldalas prózai mű szerzője fontosnak tartja, hogy már a legelején pontos eligazítást adjon arról, hogy hová, milyen térbe kívánja az olvasót bevezetni. Úgy tűnik legalábbis, mintha a szerző a mű alcímében pontosan megmagyarázná, hogy tulajdonképpen milyen részletekre és minek a részleteire utal a föcím, mi az a tágabb kontextus, amihez képest egyáltalán részletekről beszélhetünk. Az alcím magyarázata szerint egy elbeszélő életéből találunk itt emléklapokat. Eszerint a szerző itt nem egy összefüggő élettörténet feltárására vagy elbeszélésére tesz ígéretet, hanem csak bizonyos, az emlékezet számára hozzáférhető részletek előhívására. Az alcímben jelzett szerzői intenció azonban el is bizonytalanítja a biztos tájékozódási pontokat kereső olvasót. A szerző ugyanis itt nem egy elbeszélő által elbeszélt vagy elbeszélhetö történet terére, hanem egy elbeszélő életére, életterére utal. De az is zavarba ejtö, hogy miként értelmezzük az emléklap, emléklapok megnevezést egy elbeszéló életére és ugyanakkor egy prózai müre vonatkoztatva. Ha nem értettük félre ezeket az utalásokat, akkor arra gondolhatunk, hogy a szerzőnek az lehet a feltett szándéka, hogy a megélhető élet tapasztalati tereit és az elbeszélés virtuális tereit közvetlenül egybenyissa, és azt feltételezi, hogy az elbeszélői lét egy olyan kitüntetett állapot, mely ezt a két dimenziót nem eltávolítja, hanem éppen összeköti egymással. Számomra legalábbis azt sejteti, hogy a szerző itt nem egyszerüen valamit valahol valamikor akar megmutatni, érzékelhetővé tenni, vagyis nem egy reális élettér vagy egy virtuális világ körvonalait akarja felvázolni, hanem inkább magának az elbeszélői létállapotnak a különböző dimenzióit akarja megnyitni és bejárni. Azt hiszem, ez az értelmezés további magyarázatra szorul. Megítélésem szerint az elbeszélői tudat valóságértelmezői és fiktív valóságokat teremtő kompetenciája Nádas életmüvének egyik fontos és többszörösen reflektált kérdése.

Az Emlékiratok könyve című regényében például a saját élettörténetként elbeszélt történet és a fiktív elbeszélés közötti viszony kérdését Nádas egy fiktív történet keretében tematizálta. A regényben párhuzamosan olvasható három történet ugyanannak a névtelen elbeszélőnek az elbeszélése: az egyik egy fiktív történet, a másik kettőben pedig az elbeszélő saját életeseményeivel közvetlenül foglalkozik. Az elbeszélő identitása e regényben ebből a három történetből rajzolódik ki: a vallomás, az emlékezés és a fantázia lényegében az önismeret különböző eszközeiként szolgálnak. A névtelen elbeszélő történeteinek a regényen belül van egy külső viszonyítási pontjuk is - ez az egyik szereplő és ugyanakkor az implicit szerkesztő által elbeszélt, közbeékelt történet - a szerző így élesen rávilágít a regényen belüli reális és fiktív terek közötti összefüggésekre. 
Amint az előzőekben áttekintettük, a Világló részletek címü müve esetében a szerző már az alcímben is jelzi, hogy az elbeszélöi léttel, az elbeszélő lehetséges élettereivel kapcsolatos kérdések itt is fókuszban állnak, és azt is sejteni engedi, hogy itt nem a fantázia, nem a képzelet által bejárható utak, hanem az emlékező tudat lehetőségei foglalkoztatják.

Nádasnál a saját emlékképek közvetlen feldolgozásának és elbeszélésének is van elözménye. Saját halál címü írásában az elbeszélő én részben azokat a képeket hívja elő, melyeket tudatának valamely tartománya a klinikai halál állapotában rögzített, és a felélesztés után is megörzött. Az elbeszélő én egy önmagát és környezetét öntudatlanul is megfigyelö én tapasztalataira támaszkodik. Az a saját testélmény és a világnak az a sajátos percepciója, amit e megfigyelö én a klinikai halál állapotában, illetve azt megelözően és azt követően látott, tapasztalt az emlékezés folyamatában emlékként hozzáférhető, és az elbeszélő én számára megközelíthetö. A Saját halál címü írás egyes szám első személyü elbeszélője az elbeszélés szituációjában hozza felszínre azokat a rejtett tudattartalmakat, melyek az elbeszélés szituációjához képest korábbi és az életét döntő módon befolyásoló eseményekhez köthetőek.

Ha a Világló részletek címủ mü szövegét és e szöveg konstrukciós elveit vizsgáljuk, szerintem könnyen beláthatjuk, hogy a Nádas Péter nevü egyes szám első személyü elbeszélőt itt is hasonló kérdések foglalkoztatják: milyen emlékképeket képes előhívni saját tudatából, az előhívott emlékképek miként érintkeznek más emlékekkel, s ezek az asszociációs láncolatok az elbeszélő jelenbeli tudásának horizontjában miként értelmezhetők. Az elbeszélő véleményem szerint itt a tudat természetes kognitív funkcióira támaszkodik: a szabad asszociációkra való képességet itt az emlékezés szolgálatába állítja, egyfajta mnemotechnikaként alkalmazza, s ezt a „nyersanyagot” ötvözi a racionalitás képességével, illetve a racionális tudás tárgyszerű anyagával. Itt a saját életét valamiképpen élő és a saját világképét valamiképpen alakító én múltba vesző élményei és tapasztalatai válnak az elbeszélő jelenbeli megfigyelésének tárgyává.

A megfigyelt, a megfigyelő és az elbeszélő én hármasságára építő szövegszervezési technika sem újszerü eljárás Nádas prózájában. Az Évkönyv címü esszéregényében a tudat személyes tapasztalatainak, illetve bizonyos kollektív tudattartalmaknak a felszínre hozása hasonló analízis eredménye. Ebben a fiktív világok illúziójával ugyancsak szakító esszéregényben az elbeszélő egy közvetlen tudatanalízisre vállalkozik. Ennek a tudatanalízisnek egyrészt a saját személyes tudatának a felszíni és a megfigyelő számára még elérhető mélyrétegei képezik a tárgyát, másrészt a kollektív memória valamely szegmensének a megközelítése, értelmezése. A megfigyelő én látókörébe olyan közösségi történetek, olyan kollektív emlékek is belekerülnek, melyek kívül esnek a szubjektum személyes 
tapasztalati körén. Az egyik fejezetben például az elbeszélő a személyes szabadság és közösségi jog kérdéseit a római polgárháborúig vezeti vissza, és Livius történetírását követve gondolja újra. Vagyis a megismerö én személyes életterének aktuális tapasztalatai mögött az elbeszélö képes egy tágabb tapasztalati teret is megnyitni. Mintha a megismerő én személyes kérdéseire nemcsak a személyes tapasztalat vagy személyes emlékek felől, hanem valamiféle közösségi tapasztalat, már korábban megszerzett közös emberi tudás felől is érkezhetnek válaszok. Nádas én elbeszélöje már ebben az 1989-es évhez köthetö memoárban sem csupán a szubjektumként definiált én önmaga köré záruló világának a feltárására tesz kísérletet, hanem ennél többre: az önmagán kívüli világ megismerésére. Ehhez itt egyfelöl adott az évkönyv klasszikus müfaja, mely alkalmas keret a személyes és aktuális életesemények rögzítésére, másfelöl pedig adott egy korábbi elbeszélés, melyet a kulturális memória őriz. A személyes tapasztalattól és személyes emlékektől ezekig a kollektív emlékekig vezet el az elbeszélő.

Azt hiszem, nem túlzás, ha arra a megállapításra jutunk, hogy Nádas müvei már a 80-as évek óta következetesen és megkerülhetetlenül felvetik azt az alapvetö ismeretelméleti kérdést, hogy miként jut el a megismerésre törekvő ember „a létezéstöl a létig”, az egyénitől a közös tapasztalati térig. Ugyanakkor Nádas regényei azt a kérdést is következetesen felvetik, hogy az elbeszélő hogyan tudja integrálni a megismerés számára közvetlenül adott világ tapasztalatát, illetve a lehetőségként, a szabad teremtés és önteremtés lehetőségeként elgondolt ötleteket, terveket, fantáziákat, vagyis azt a kérdést, hogy az elbeszélés mint köztes tér miként ötvözi az adott világ tapasztalatát és a lehetséges elképzeléseket, a lehetőségekként elgondolt élethelyzeteket. Értelmezésem szerint az elbeszélő én tudatmozgása és e mozgás változásának iránya a Világló részletek című mü esetében is releváns szervező elv, mely meghatározza a szöveg textúrájának felszíni mintázatát és szerkezetének alakulását. Hogyan?

A több mint ezeroldalnyi szöveg két nagy részre tagolódik. A két nagy szövegtömb két külön kötetet tesz ki, és a két külön kötetnyi szöveg formailag csak a bekezdések szintjén tagolódik további alegységekre. Mintha az elbeszélés folyamának nem is lennének kívülről szabályozott vagy szabályozható nyugvópontjai, és az elbeszélői én valóban valamilyen belső szempontokat követne. Ha viszont az olvasó az elbeszélő én belső nézőpontjának nyomvonalát követi (márpedig nincs is más választása), akkor kiderül, hogy a szöveg szerkezete nagyon is fragmentált. Amiként ezt a cím is már elöre jelzi.

Ez az elbeszélö ugyanis arra tesz kísérletet, hogy felidézze azt a kognitív folyamatot, amely révén életének első tizennégy évében a világot valahogyan és valamilyennek megismerte. De az elbeszélő az utólagos reflexió folyamatát is tudatosan nyomon követi: az emlékező tudat valahonnan emlékezik, egy hatá- 
rozott tudáshorizont felöl közelít. A szabad asszociációk láncolatában felbukkanó emlékképek később szerzett felismerésekhez, belátásokhoz vagy kimondott kutatómunka során szerzett információkhoz kapcsolódnak, s az elbeszélö lényegében annak a történetnek a folyamatát tárja fel előttünk, hogy a felidézett emlékképek miként idéznek fel újabb emlékeket, s az emlékképek láncolata miként egészül ki a mások elbeszéléseinek emlékével, illetve mindezt hogyan és mivé alakítja az értelmező tudat. Az elbeszélő a saját tudatműködését figyeli és rögzíti. Csakhogy ennek a folyamatnak az anyaga maga a nyelv, ki kell mondani a szavakat és össze kell kötni őket ahhoz, hogy összeálljon egy emlékkép. És a nyelv mágneses ereje segít ezt összekapcsolni egy másik emlékképpel. Az értelmezés közege ismét csak a nyelv. Vagyis az emlékezés folyamata és az értelmezés fázisai nem függetlenek az elbeszélés folyamatától, hiszen azon belül működnek. Az elbeszélés folyamata integrálja az emlékezés önkéntelen és spontán folyamatait, de nem merül ki ebben. Az elbeszélő magára az elbeszélésre, az elbeszélés folyamatára is reflektál, többszörös kitérő után is visszatér az elkezdett történethez, visszakapcsol a kiindulóponthoz, továbbszövi az elkezdett történetet, majd újra és újra megszakítja további asszociációkkal és további magyarázatokkal. Az elbeszélés folyamatában az analógián alapuló tudatmüködés kiegészül egyrészt a reflexív tudatmüködéssel, másrészt a racionális összefüggéseket kereső tudat logikájával. Az emlékezés folyamatán belül pedig szimultán képek és lineáris történetek egyaránt felidéződnek.

Nézzük először az első rész példáját. Mindkét résznek önálló címe is van. Az első rész címe: Amikor szerdán. A cím az elbeszélő születésének napjára utal, és az elbeszélő ebben a kötetben valóban beszámol születésének konkrét körülményeiről is aszerint, ahogyan gyerekkorában anyjától, majd később magától a szülészorvostól értesült ezekről a részletekről. A saját születését felidéző történet részleteivel párhuzamosan az elbeszélő egy másik történetet is felidéz, a holokauszt történetének azokat az eseményeit, melyek éppen ezen a napon estek meg. Ezeknek az eseményeknek a rekonstruálásához történelmi dokumentumokat használ. Konkrétan hivatkozik például az amerikai holokausztkutató Christopher R. Browning forráskutatásaira, Anne Frank és Viktor Klemperer naplójára, a korabeli magyar sajtóra, hadi közleményekre, kormányrendeletekre, jegyzőkönyvekre, helyszíni fényképekre. A születés személyes története és a tömeggyilkosságok története így közös lapra kerül.

[...] azon az októberi szerdán, abban a korai órában, amikor anyámnak a Pozonyi úton megjöttek az első fájásai, egy német különítmény, a hamburgi 101. tartalékos rendőrzászlóalj épp azon volt, hogy a világ hallgatólagos egyetértésével felszámolja a mozoczi gettót. Ami egészen 
konkrét formában azt jelentette, hogy születésem napján Hoffmann százados parancsának engedelmeskedve 1259 korábban listára vett embert hajtottak ki a városokból a közeli kőfejtőkbe. Ott a nőket és a gyerekeket elválasztották a férfiaktól ezen a szerdán. Anyaszült meztelenre kellett levetkezniük ezen a szerdán. Olyan mezítelenre, ahogy anyám a budapesti Szabolcs utcában, a nagy hírű nőorvos, Hirschler Imre segítségével a Zsidó Kórház szülészetén a világra tolt. [...] Anyám egy szál könnyủ selyemruhában villamosozott be a kórházba, ahogy később elmesélte. Úgy mondták, hogy hernyóselyem (Nádas 2017, I. 376-377).

A párhuzamosan elbeszélt születés- és holokauszt-történetbe más történetek és emlékképek is beékelődnek. Például az elbeszélő kamaszkori emlékei, melyek ugyanahhoz a környékhez kapcsolódnak, ahol a szülészet épülete van, vagy az ellenállási mozgalom története, melyben a szülei is aktívan részt vettek. Szüleinek az ellenállási mozgalomban végzett tevékenységét ugyancsak a gyerekkorában hallott és az emlékezetében megőrzött történetek alapján rekonstruálja.

Főleg anyám elbeszélésére, apám néhány mondatára és gesztusára, azaz az emlékezetemre hagyatkozom. Az írásbeli források az emlékezetemnél sem kevésbé megbízhatatlanok. Anyám többször visszatért a témára, szinte mániákusan tért vissza rá, minduntalan újabb részlettel szolgált, amit az elmém ugyan alig volt képes befogadni, mégis készségesen elraktározott (Nádas 2017, I. 387).

Az elbeszélő születésével kapcsolatos történetnek a holokauszt felidézett eseményein kívül van egy másik ellenpontja is: az anyja halálának története. Ezt a történetet az elbeszélő már a 11-12 éves fiú emlékei alapján meséli el.

Még haldoklásában is másként láttam anyának az anyánkat. Gyenge volt, besárgult, a haja a besugárzásoktól kihullt, teste felfúvódott és vizenyősen feldagadt, de nagy nevetgélések közepette azt mondogatta, hogy ő igazán elvan. Ennyire még soha nem kényeztették el, mindennap friss hálóinget adnak neki. Nevetése azért megmaradt. Csak valami finomságot, például gondosan hámozott luftballont szeretne enni (Nádas 2017, 403-404).

A saját születésének részleteit az elbeszélő az anyja elbeszélése alapján tudja elmesélni, az anyja halálának előzményeit pedig a saját gyerekkor emlékei alapján.

Az elbeszélő a kötet elején a saját tudatában felidézhető emlékképek nyomain indul el. Felidézi például egy égő ház és egy leomló fal képét. Ehhez a látványhoz a zuhanás élménye társul. Többször visszatér ehhez a képhez, és próbálja beilleszteni azoknak az eseményeknek a sorába, melyeket a családtagjai elbeszé- 
léseiből ismer. Az utólagos rekonstrukció alapján úgy véli, hogy ez a legrégebbi személyes emléke, és Budapest ostromához kapcsolódik, mégpedig ahhoz a pillanathoz, amikor a házukat bombatalálat érte, és a leomló fal őt és az őt védelmező anyját is maga alá temette. Ugyanezt az eseményt a nagynénje is elmesélte neki, és így a saját tudatában rögzült és megőrzött életesemény emlékét össze tudja vetni a nagynénje elbeszélésével. Hasonlóképpen az uborkaevés emlékét utólag azokhoz az eseményekhez tudja illeszteni, melyek a bácskai meneküléssel kapcsolatosak, és melyeket ugyancsak a családi történetből ismer. A nagyapjával folytatott közös játékok emlékéhez nemcsak képek, hanem érzetek is társulnak, s ezek a nagyapához füződő első emlékképek és érzetek szintén a tágabb családtörténet felé vezetnek.

Miközben az elbeszélő a saját gyerekkori tapasztalatait rekonstruálja, újraértelmezi, elrendezi, egy családtörténet bontakozik ki. A kötet címe sem véletlen. Hiszen éppen ebből a perspektívából, az elbeszélő meghatározott szemszögéből rajzolódik ki a szüleivel és nagyszüleivel közös gyerekkor története, a szülei tőle független élettörténete, a nagyszülők, nagybácsik, nagynénik és dédszülők életének bizonyos epizódjai. Az elbeszélő én ebben a kötetben saját gyerekkori tudatának észleléseihez, képként, történetként vagy másfajta tudásként elraktározott és emlékként őrzött tapasztalati tudásához próbál hozzáférni. Identitástörténetét saját öntudatának és világalkotó képességének a müködési folyamataként ragadja meg, rakja össze és alkotja meg az elbeszélés folyamatában. A megismerő gyerek számára a külvilág nyitott tér. A családi viszonyokról, kapcsolatokról nem is leválasztható a saját alakuló én- és világképe. Az elbeszélő tehát a maga retrospektív technikájával egyrészt felidézi ennek a nevelődési folyamatnak a konkrét fázisait mint világló részleteket, de ezek nem egy lineáris élettörténetbe vagy egy koherensen elbeszélt családtörténetbe épülnek bele. Ezek a részletek az emlékezö és az elbeszélö én tudatfolyamának az elemei lesznek, maradnak.

A második rész címe: Marcellina feláldozása. Ennek a címnek kulturális konnotációi vannak. Maga az elbeszélő is elmeséli azt a megrázó élményét, amikor hatévesen először látta Beethoven Fidelio címü operájának előadását. Az opera szereplőinek álságos viselkedése, ahogyan becsapják és félrevezetik egymást, mélységesen felháborította. Külön felháborítónak tartotta, hogy Leonora megtévesztő játszmájához még mentségül is szolgál a férje kiszabadítása, hogy megfelelö indokkal az egyik ember becsaphatja a másikat. Nem tartotta hihetőnek, hogy Marcellina ilyen könnyen felül a látszatnak, és habozás nélkül elhagyja Jaquinót, akit tegnap még szeretett. Nem tartotta elfogadhatónak, hogy az emberek ilyen könnyen elárulják egymást, és azt sem, hogy ezek az egymás ellen elkövetett konkrét és személyes árulások, megtévesztő játszmák valamilyen előbbrevaló vagy fontosabbnak tartott szempontból még helyeselhetőek is. 
A gyerek ösztönös ellenérzéseit és tiltakozását megerősíti a felnőtt értelmezése: miért tartja valóban tévútnak azt a kulturális modellt, mely a személyesség és a személyes emberi viszonyok felől értelmezhetetlen fantazmagóriákra épít, a közjó nevében megfogalmazott erkölcsi szentenciákra, kitalációkra, látszatra.

Mi változik meg ebben a kötetben az előzőhöz képest? Ebben a részben az elbeszélő személyes emlékei jórészt annak a fiúnak a világtapasztalatával kapcsolatosak, aki megtapasztalja a látszat és a látszat mögötti valóság közötti különbséget. A szülei, a nagynénje és felnőtt családtagjai viselkedése mögött próbálja megérteni azt, amit elfednek, elhallgatnak vagy eltitkolnak. Az elbeszélő pontosan felidézi az első olyan esetet, amikor gyerekként rádöbben arra, hogy az unokatestvére és nagynénje rágalmazásával szemben nem tudja megvédeni a saját igazát a szülei előtt. Hogy a látszat ellene szól, de nem a látszat az igazság. A látszat által elfedett igazság megértésének igénye igazi fordulópontnak számít ennek a kisfiúnak a nevelődéstörténetében.

Vagy mindent jól látnak, jól értenek, s akkor a jóság lenne az álca, ez is felmerült. A felnőttek nem arcot, hanem maszkot hordanak. De nem azért viselik, hogy jók lehessenek, hogy jók legyünk, hanem azért viselik, hogy jól megfontolt és jól kiszámított gonoszságunk ne lehessen személyes boldogságunk akadálya. A gonoszság édenében kell a gonoszság ellen védekeznünk. Nem is lett volna ellene kifogásom. Az örök béke érdekében viseljünk háborút. Ha nagy leszek, akkor majd én is ezt teszem. De addig mit kezdjek a viselkedési szabályok szigorával és a bombasztikus erkölcsi retorikával, ha egyszer a szavak miatt nem értem, hogy mit kéne megértenem (Nádas 2017, II. 204).

Ezzel a dilemmával való szembesülését az elbeszélő gyerekkori tapasztalataihoz köti, majd későbbi, felnőttkori tapasztalatai felől is megerősíti ennek a dilemmának a jelentőségét.

Ötven évnek kellett eltelnie, a világégésekről és a szisztematikus emberirtásokról szóló irodalmat soronként, valamennyi lábjegyzetével együtt kellett átböngésznem hozzá, hogy legalább Vrbával és Levivel együtt lelássak a szakadékba, amely az európai teológia, az európai humanizmus, az európai felvilágosodás és a mindenkori európai realitás között mozog (Nádas 2017, II. 206).

A gyerek valóságra eszmélésének története az egyik fontos szál, amit az elbeszélő itt nyomon követ. Egyfelől a szülei elvárásait és a szülei szempontjait próbálja megérteni. De ugyanakkor az iskolában is ki kell ismernie magát a szerepjátékok és hatalmi játszmák viszonyai között, ha meg akarja védeni magát 
az osztálytársai erőszakos támadásaival szemben. A szülei elvárásai és a konkrét élethelyzet realitása az iskolásfiú tapasztalata szerint nincsenek összhangban egymással. Hogyan maradhatna jó és elfogadó anélkül, hogy ne válna az osztálytársai erőszakos támadásainak áldozatává? Vagyis az elbeszélő egyrészt saját nevelődésének fázisait, ennek a folyamatnak az emlékezetében megőrzött nyomait tárja fel.

A fiú önmagára eszmélésének történetével párhuzamosan nyomon követhetjük a szülők pályafutásának, politikai meggyőződésének és magánéletének alakulását is a negyvenes évek végétől az ötvenes évek első feléig, egészen halálukig. Ez a történet bizonyos pontokon ugyancsak az elbeszélö személyes emlékeire támaszkodik. De a személyes emlékeket későbbi forráskutatások egészítik ki. Az elbeszélő nemcsak a gyerek nézőpontjából szeretné szülei élettörténetét rekonstruálni, hanem azon reális és dokumentált tények ismeretében, melyek a gyerek számára nem voltak hozzáférhetők. Szülei szakmai és politikai pályafutásának történetét levéltári dokumentumokra támaszkodva pontosítja. A szülei tragédiája - anyja betegsége és halála, apja összeomlása és öngyilkossága - a gyermek szemei előtt zajlik, és ennek a családi összeomlásnak a története az elbeszélő személyes emléktárában fellelhető. De a szülei tragédiája mögött rejlő okokat, magyarázatokat a felnőtt értelme tudja megtalálni és megadni.

[...] ideáikat és utópiájukat csak úgy tudták átmenteni a következő hétre, ha ezen a héten még mindig személyes hibának látták a rendszerhibát, és mindenre találtak gyorsan egy bünbakot. A tabu alatt tartott, később törvénytelenségnek elkeresztelt sorozatgyilkosságaik és tömeggyilkosságaik csak kevesek ínyére voltak, ez igaz, de mégis úgy hallgattak ezekröl, mintha saját maguk követték volna el. Nem erről beszéltek, illetve mindig csak képletesen beszéltek erről. Volt miért hallgatniuk. A jogállam ellen elkövetett puccsal az embertelenség történetének új fejezetét nyitották meg, és ezt a fejezetet írták tovább a terrorral. Maradéktalanul, ez volt a szlogenjük, tévedhetetlen pártjuk utasításait maradéktalanul kell végrehajtani (Nádas 2017, II. 422).

Szülei tragikus története a magyarországi és részben európai baloldali mozgalmak történetébe ágyazódik, és szembesít a kommunista értelmiségi körök alapvető tévedéseivel, csúsztatásaival. Az elbeszélő nem a szülei jó szándékát, önzetlen segítőkészségét, a közösség iránti lojalitását és önfeláldozását kérdőjelezi meg. Megítélése szerint a szülei nem voltak képesek átlátni a kommunista ideológia alapvető tévedésein, valóságos lehetőségként fogadták el és tették magukévá azokat a szempontokat, melyeket a társadalmi gyakorlatban csak hatalmi eszközökkel lehetett alkalmazni. Ezért a politikai értelemben vett naivitásukért 
és vakságukért komoly árat kellett fizetniük, éppen azért, mert a mindennapi tapasztalataik ellenében is komolyan vették elveiket, nem voltak képesek belátni ideológiai tévedéseiket. Az elbeszélő azt is belátja, hogy szülei saját társadalmi osztályuk hagyományaival, saját polgári kiváltságaikkal mentek szembe, amikor fiatalon bekapcsolódtak az illegális kommunista párt munkájába, és magukévá tették a kommunista nézeteket. A valóságként felfogott látszat olyan csapda, melybe az elbeszélő értelmezése szerint a szülei, nagynénje és hithű elvtársaik egyaránt belesétáltak. „Színjátékot mutattak be neki, s ő valóságként fogadta el” (Nádas 2017, II. 83). Az illegális kommunista mozgalom és a magyar fasisztaellenes mozgalom történetének körvonalai nemcsak az elbeszélő szüleinek élettörténetéből rajzolódik ki, hanem a tágabb családtörténetből és a családi hagyaték dokumentumaiból.

Nádas úgy ír családtörténetet, hogy a saját tudatmozgását követi, és azt is leképezi. Nem külső szempontokat követ, nem valamilyen külsődleges formai szabályokhoz igazodik, és nem veszi figyelembe az események kronológiai rendjét sem. Azokból a korai emlékképekből indul ki, melyeket a saját tudatában fel tud idézni, s később is a saját emlékei nyomvonalát követi. Ezeket az emlékképeket és az emlékezetében őrzött történeteket integrálja a később szerzett tudás keretébe, kiegészíti a mások által elbeszélt történetekkel, illetve a saját forráskutatási eredményeivel. Úgy ír családtörténetet, ahogy az ő tudata őrzi és feldolgozza a családi történeteket. Ezért beszélhet emléklapokról és ezért beszélhet egy elbeszélő életérőll. Ezt az elbeszélőt nemcsak a saját szubjektív világa foglalkoztatja, hanem mindaz, amit egy elbeszélő képes lehet hitelesen elbeszélni. A felidézett gyerekkor ablakot nyit az egész család történetére. Az így elbeszélt családtörténetek pedig ablakként nyílnak azokra a történelmi korokra, korszakokra, melyben az egyes családtagok éltek és alakítottak. A szülők, nagynénik és nagybácsik élettörténete összefonódik az illegális kommunista mozgalommal, az ellenállási mozgalmakkal, a második világháború utáni politikai mozgalmakkal, a rákosi rendszerrel. A dédapja és dédapja öccsének élettörténete pedig a magyar polgári demokráciáért és az egyenjogúságért folytatott jogi és politikai küzdelmekkel. Az anyai nagyszülei élettörténete a pesti zsidó kispolgárok életformáját tükrözi. Anyai nagynénje ízlése és lakásának berendezése a modern magyar képző- és iparmüvészethez igazodik. Apai nagyapja kitart szociáldemokrata meggyőződése mellett, ügyvéd nagybátyja pedig következetesen a többpártrendszeren alapuló parlamentáris demokrácia jogrendjét képviseli az egypártrendszer diktatúrájával szemben. Az eszmélő gyerek nem egy, hanem többféle modellt lát maga előtt, és láthatja, ha gyerekként még nem is érti pontosan, szülei életének tragédiáját. A családtörténet mellett egy gyerek nevelödéstörténete is ez a könyv: mit és hogyan ért meg a világból, mit fogad el, milyen döntéseket hoz. A valamikori 
gyerek és az elbeszélő igénye, szándéka lényegében nem különbözik: megérteni azt a világot, melyben él, megérteni a látszat és a valóság közötti különbséget, megérteni a sokarcú látszat mögötti valóságot. A látszatok mögötti valóság kérdése foglalkoztatja már a hatéves gyereket is. A sokféle látszattól eltakart igazság kérdése foglalkoztatja az elbeszélőt is. Szerinte ez nemcsak filozófiai vagy teológiai kérdés, hanem a mindenkori elbeszélő szakmai kérdése is. Az elbeszélés folyamán egy olyan úton indul el, mely ebbe az irányba vezet: megpróbál a családi, társadalmi és kulturális konvenciók mögé nézni. És ebbe a köztes térbe vezeti be az olvasót. A Világló részletek elbeszélője az elbeszélés köztes terében az önmegértés és a világ megértésének lehetőségeit mérlegeli.

\section{Kiadások}

Nádas Péter. 1986. Emlékiratok könyve. Budapest: Szépirodalmi Könyvkiadó.

Nádas Péter. 1989. Évkönyv. Budapest: Szépirodalmi Könyvkiadó.

Nádas Péter. 2004. Saját halál. Pécs: Jelenkor.

Nádas Péter. 2005. Párhuzamos történetek. Pécs: Jelenkor.

Nádas Péter. 2011. Fantasztikus utazáson. Pécs: Jelenkor.

Nádas Péter. 2017. Világló részletek I-II. Budapest: Jelenkor.

\section{Irodalom}

Assmann, Jan. 1999. A kulturális emlékezet. Budapest: Atlantisz.

Balassa Péter. 1997. Nádas Péter. Pozsony: Kalligram.

Bazsányi Sándor. 2018. Nádas Péter: A Bibliától a Világló részletekig. 1962-2017. Pécs: Jelenkor. Heidegger, Martin. 2001. Lét és idő. Budapest: Osiris.

Tengelyi László. 1998. Élettörténet és sorsesemény. Budapest: Atlantisz.

Tengelyi László. 2017. Őstények és világvázlat. Budapest: Atlantisz.

Irena BANDI

\section{OD PRISEĆANJA DO PRIPOVEDANJA}

Međuprostori u delu Petera Nadaša Világló részletek (Svetli detalji)

U ovom radu bavim se istraživanjem međuprostora u delu Petera Nadaša Világló részletek, odnosno pokušavam da istražim pravac kretanja svesti pripovedačkog ja. U prvom delu studije pokušavam da ukažem kako pripovedač prelazi granicu neposredne perceptivne svesti sadašnjosti, kako pronalazi uspomene iz prošlosti i kako može objektivno da posmatra i zabeleži sopstveno unutrašnje putovanje. Drugi deo rada takođe postavlja pitanje kako 
narator prelazi svoja subjektivna iskustva i kako dolazi do iskustava o svetu koja nisu deo njegove direktne spoznaje. U drugom delu želim da otkrijem i kako pripovedač, ne koristeći alate fikcije i mašte, dolazi do zajedničkih priča, kako prevazilazi međuprostor koji kognitivni um neizbežno opaža između sveta mene i tebe, mene i drugog.

Ključne reči: lično pamćenje, kolektivno pamćenje, intersubjektivni prostor, životna priča, memoari

\section{Irén BANDI}

\section{FROM REMEMBERING TO STORY-TELLING}

\section{Intermediate Spaces of Péter Nádas's Work Világló részletek (Bright Details)}

In this study, I explore the intermediate spaces of Péter Nádas's work Világló részletek and more specifically, I try to explore the direction of consciousness movement of the first-person narrator. In the first part of the study, I attempt to grasp how the narrator crosses the border of the immediate perceptual consciousness of the present, how he finds the memories of the past and how he can objectively observe and record his own inner journey. The second part of the study also poses the question how the narrator transcends his own subjective experiences, and how he reaches world experiences that are not part of his direct cognition. So in the second part, I want to track how the narrator, without using the tools of fiction and imagination, comes to common stories, how he transcends the intermediate space that the cognitive mind inevitably perceives between the world of me and you, myself and the other. Keywords: personal memory, collective memory, intersubjective space, life story, memoirs 